\title{
The Role Of Local Self-Government Bodies In Prospective Areas Of Regional Development
}

\author{
SVITLANA POPOVA ${ }^{1}$, LILIYA POPOVA ${ }^{2}$, IRINA KAZANCHHUK ${ }^{3}$, IRYNA BANDURKA ${ }^{4}$, \\ IRYNA KYRIEIEVA ${ }^{5}$ \\ ${ }^{1}$ Department of Law Enforcement and Police Studies, KHARKIV NATIONAL UNIVERSITY OF INTERNAL AFFAIRS \\ KHARKIV, UKRAINE, E-mail: svetlanap@ukr.net \\ ${ }^{2}$ Department of Finance and Credit, KHARKIV NATIONAL UNIVERSITY OF CIVIL ENGINEERING AND \\ ARCHITECTURE KHARKIV, UKRAINE E-mail: Liliya.herman01@gmail.com \\ ${ }^{3}$ Department of Administrative Law and Process, KHARKIV NATIONAL UNIVERSITY OF INTERNAL AFFAIRS \\ KHARKIV, UKRAINE E-mail: kazanchuk76@outlook.com \\ ${ }^{4}$ Department of Criminal Law and Criminology, KHARKIV NATIONAL UNIVERSITY OF INTERNAL AFFAIRS \\ KHARKIV, UKRAINE E-mail: irina.bandurka.16@gmail.com \\ ${ }^{5}$ Department of Legal Support of Economic Activities, KHARKIV NATIONAL UNIVERSITY OF INTERNAL AFFAIRS \\ KHARKIV, UKRAINE E-mail: 48.105996a@gmail.com
}

\begin{abstract}
The article is devoted to determining the priority directions of local self-government bodies' activity in the development of regions. Local self-government bodies are public entities that are empowered to deal with issues that are relevant to the well-being of the respective territorial community. Protecting the interests of the local community is a key objective of local self-government. The reform of local self-government in Ukraine is currently underway, the main purpose of which is decentralization of state power with the provision of territorial communities with resources and the mobilization of their internal reserves to provide the population with an adequate level of services. Such a goal could be achieved through effective local government action on regional development. The article analyzes the normative and legal support of the capacities of local self-government bodies to determine the priority opportunities for the development of regions and to provide support for such development. It is established that the local self-government bodies in determining the priority directions of development of the regions should take into account various factors such as: geographical, demographic, personnel, environmental, economic, historical and cultural. Attention is drawn to the need for a comprehensive approach to the analysis of such factors by local governments. The article analyzes a number of factors that have a negative impact on the current state of regional development. The directions of activity of local selfgovernment bodies to avoid or minimize the consequences of such influence on the development of regions are suggested. It has been established that local governments can use tax, information, innovation and other measures of influence in order to stimulate priority directions of regional development. The emphasis is placed on the role of local authorities in the development of tourist attractiveness of regions, in particular in the field of international and interregional cooperation as a means of forming a positive image of the regions, providing information and financial support for the development of this area of regional development.
\end{abstract}

Keywords: Local self-government, Local self-government powers, Development of territories, Regional potential, Regional development, Regional development directions, Tourism, Development strategy

JEL Classification: Q26, R13, O15, L83 


\title{
El Papel de los Órganos de Autogobierno Local en las Áreas de Desarrollo Regional
}

\author{
SVITLANA POPOVA ${ }^{1}$, LILIYA POPOVA ${ }^{2}$, IRINA KAZANCHHUK ${ }^{3}$, IRYNA BANDURKA ${ }^{4}$, \\ IRYNA KYRIEIEVA ${ }^{5}$ \\ ${ }^{1}$ Department of Law Enforcement and Police Studies, KHARKIV NATIONAL UNIVERSITY OF INTERNAL AFFAIRS \\ KHARKIV, UKRAINE, E-mail: svetlanap@ukr.net \\ ${ }^{2}$ Department of Finance and Credit, KHARKIV NATIONAL UNIVERSITY OF CIVIL ENGINEERING AND \\ ARCHITECTURE KHARKIV, UKRAINE E-mail: Liliya.herman01@gmail.com \\ ${ }^{3}$ Department of Administrative Law and Process, KHARKIV NATIONAL UNIVERSITY OF INTERNAL AFFAIRS \\ KHARKIV, UKRAINE E-mail: kazanchuk76@outlook.com \\ ${ }^{4}$ Department of Criminal Law and Criminology, KHARKIV NATIONAL UNIVERSITY OF INTERNAL AFFAIRS \\ KHARKIV, UKRAINE E-mail: irina.bandurka.16@gmail.com \\ ${ }^{5}$ Department of Legal Support of Economic Activities, KHARKIV NATIONAL UNIVERSITY OF INTERNAL AFFAIRS \\ KHARKIV, UKRAINE E-mail: 48.105996a@gmail.com
}

\begin{abstract}
RESUMEN
El artículo está dedicado a determinar las direcciones prioritarias de la actividad de los órganos de autogobierno local en el desarrollo de las regiones. Los órganos de autogobierno local son entidades públicas que están facultadas para ocuparse de cuestiones que son relevantes para el bienestar de la respectiva comunidad territorial. La protección de los intereses de la comunidad local es un objetivo clave del autogobierno local. Actualmente se está llevando a cabo la reforma del autogobierno local en Ucrania, cuyo objetivo principal es la descentralización del poder estatal con la provisión de recursos a las comunidades territoriales y la movilización de sus reservas internas para proporcionar a la población un nivel adecuado de servicios. Este objetivo podría alcanzarse mediante una acción eficaz de los gobiernos locales en materia de desarrollo regional. El artículo analiza el soporte normativo y legal de las capacidades de los órganos de autogobierno local para determinar las oportunidades prioritarias para el desarrollo de las regiones y proporcionar apoyo a dicho desarrollo. Se establece que los órganos de autogobierno local al determinar las direcciones prioritarias de desarrollo de las regiones deben tener en cuenta diversos factores como: geográficos, demográficos, de personal, ambientales, económicos, históricos y culturales. Se llama la atención sobre la necesidad de que los gobiernos locales adopten un enfoque global para el análisis de dichos factores. El artículo analiza una serie de factores que inciden negativamente en el estado actual del desarrollo regional. Se sugieren las direcciones de la actividad de los órganos de autogobierno local para evitar o minimizar las consecuencias de dicha influencia en el desarrollo de las regiones. Se ha establecido que los gobiernos locales pueden utilizar los impuestos, la información, la innovación y otras medidas de influencia para estimular las direcciones prioritarias del desarrollo regional. Se hace hincapié en el papel de las autoridades locales en el desarrollo del atractivo turístico de las regiones, en particular en el ámbito de la cooperación internacional e interregional como medio para formar una imagen positiva de las regiones, proporcionando información y apoyo financiero para el desarrollo de este ámbito del desarrollo regional.
\end{abstract}

Palabras claves: Autonomía local, Poderes de la autonomía local, Desarrollo de los territorios, Potencial regional, Desarrollo regional, Direcciones de desarrollo regional, Turismo, Estrategia de desarrollo

Clasificación JEL: Q26, R13, 015, L83 


\section{Introduction}

Ukraine has embarked on the path of European integration. Significant reforms are underway in the country, one of which is local government reform. The main purpose of this reform is the decentralization of power by providing territorial communities with resources and mobilizing their internal reserves to provide an adequate level of service to the population. The importance of the reform is to ensure the regional development of the country through decentralization of power, to promote the formation of local self-government capable of meeting the needs of the local population through active participation in the socio-economic development of the region. Local governments have an important role in the life of the country; they are much more than the state authorities close to the interests of ordinary citizens who form territorial communities of villages, towns and cities of the country. Therefore, local governments are most aware of the direct effect of national and regional factors of negative and positive content that affect the needs of the local population. One of the most important directions and tasks of the activity of local self-government bodies is the analysis of those factors that can positively influence the development of the respective region and provide municipal legal support for the identified promising directions of development. The formation and development of the system of local democracy in Ukraine is seen as one of the most important socio-political and legal factors for the improvement of democratic statehood, the approximation of public authority to citizens, an important means of forming the competence of territorial communities and the local selfgovernment bodies formed by them.

\section{Literature review}

Authors such as N. Kaminskaya and V. Senchuk have considered the importance of local selfgovernment as a certain power conferred on territorial communities by the Basic Law of the country. The powers of local governments have been explored in various capacities. For example, in the work of E. Brodin and I. Lenenko, they were seen as an object of reformation for the distribution of these powers between different levels of local self-government. However, the mentioned authors did not address the specific issues of improving such powers or directing them to the development of their respective regions. The works of V. Safiullina considered some directions of development of the country, namely considered the resource base of Ukraine for the development of tourism and the state action in this direction. In the works of Y.Stavska the main negative factors influencing the inhibition of tourism development in Ukraine in the conditions of influence of factors of the world market were considered. At the same time, the works of the mentioned authors did not investigate the actions of local self-government bodies as subjects capable of promoting tourism development in the regions of the country. $O$. Shevchenko in his work on the basis of the analysis of strategies of economic and social development of the regions of Ukraine identified the theoretical problems of improving regional development priorities. However, there are no recommendations in the author's work to identify specific areas of such development (Alghamdi et al 2017).

\section{Data and methodology}

The purpose of the study is to determine the priority areas of activity of local self-government bodies in terms of perspective directions of regional development. Pursuant to the goal, the following tasks were formulated: to analyze the regulatory and legal support of the capacity of local selfgovernment bodies to identify priority prospects for the development of regions and to ensure support for such development; explore a number of factors that have a significant impact on the current state of development of the regions; identify the fundamental capacity of local governments to avoid or minimize the consequences of negative impact on the development of regions by actively exercising their competencies for promising areas of regional development.

To solve these tasks and achieve the goal of the study, a set of general scientific and special methods of knowledge of social and legal phenomena was used. The dialectical method was used to find the right approaches to solving the theoretical and legal problems that arise due to the action of a range 
of factors that adversely affect the state of development of Ukrainian regions. The comparative legal method was used in the analysis of the theories that determine the foundations of the activities of local governments. The statistical method is for analyzing the phenomena and processes that influence the choice of perspective directions for the development of regions. The synergistic method was used to reveal the multilevel of factors affecting the current state of social and economic development of Ukraine as a whole and its regions, to understand ways of overcoming the negative manifestations of existing factors in conditions of legal stabilization. The axiological approach was used to determine the content and direction of the development of actions of local self-government bodies in the exercise of powers aimed at supporting the promising directions of regional development. The following general scientific methods of cognition have been used: systemic method - for the study of powers of local self-government bodies as a certain system of mutually agreed actions; structural method - for the study of the spheres of activity of local self-government bodies to stimulate regional development; functional method - for disclosing the powers of local governments.

\section{Results}

According to Article 140 of the Constitution of Ukraine [1], local self-government is the right of a territorial community (residents of a village or voluntary association of residents of several villages, towns and cities) to independently decide on issues of local importance within the framework of the Constitution and laws of Ukraine. In the legal literature, there are various approaches to uncovering the content of the concept of local self-government. Here are some of the following approaches: According to N. Kaminska, local self-government is an organizational form of exercise of power by the population in the field, which is intended to provide independent (under its responsibility) solutions to issues of local importance to citizens living within the territorial unit, based on the interests of the population, historical and local traditions [2, c. 11]. According to V. Senchuk, who considers local selfgovernment from the standpoint of the theory of a democratic state, it becomes a necessary factor for the formation and development of a democratic state, which is connected with the functioning of the system of social relations management through self-activity and self-regulation, for which the respective rights and opportunities are given as separate citizens and their territorial communities acting within the law and under their own responsibility $[3, p .20]$. The above definitions do not contradict the definition given by the Basic Law of Ukraine, but only reveal the importance of local selfgovernment as a form and method of organizing local authority. The definition provided by the Constitution summarizes the very essence of local self-government - the voluntary unification of the population on the basis of community living in order to protect their local interests through the exercise of the powers provided by law. It should be noted that local self-government is realized through the responsible local self-government bodies responsible for its implementation: village, settlement, city councils and their executive bodies, as well as representatives of common interests of territorial communities of villages, towns and cities - district and region councils. Based on the above, we can conclude that local self-government bodies are representative bodies that are empowered by the democratic election of representatives of territorial communities to resolve issues within the competence of local self-government. In the light of local government reform, which seeks to increase its role in the life of the country and to address local issues within its competence, local governments should be empowered to carry out such tasks.

\section{Discussion}

Therefore, it is advisable to analyze what powers and in what areas are given to local governments to address the challenges of their existence. Such powers are contained in a special regulatory act the Law of Ukraine "On Local Self-Government in Ukraine» [4]. Based on the analysis of the provisions of Chapter 1 of the second section of the aforementioned law on the powers of village, settlement and city councils, it is possible to identify certain groups of powers that can be used to promote the development of promising areas of regional development: 
1. Powers of an organizational nature. Local self-government bodies approve programs of socioeconomic and cultural development of the respective administrative-territorial units, targeted programs on other issues of local self-government. Local self-government bodies also have organizational powers, in particular, to decide on the creation, liquidation or organization of municipal legal entities, and decide on the creation of joint ventures, including with foreign investments, by municipal enterprises. Local self-government bodies can promote local self-organization activities to resolve local issues by deciding on the self-organization of the population with separate local selfgovernment powers, as well as transferring funds, logistical and other resources necessary for their implementation.

2. In the field of interregional and international cooperation, they are empowered to: make decisions on association in associations or join associations, other forms of voluntary associations of local self-government bodies and on their withdrawal; approving agreements on the integration of Euroregional cooperation, taking decisions on the formation of the association of Euroregional cooperation, on joining or withdrawing from such association, approving the statute of association of Euroregional cooperation and amending it; making decisions on joining and leaving the European Territorial Cooperation Association.

3. Powers of a financial nature. Local self-government bodies also have considerable financial powers that are appropriate to use to promote the development of certain areas of activity identified by them as priorities: consideration of the local budget forecast, approval of the local budget, amending it; approval of the report on implementation of the relevant budget; setting local taxes and fees; creation of trust funds, approval of provisions on these funds; the formation of local cinema financial support funds, including grant, competition or non-competition cinema support programs, the definition of the terms and conditions of use of these funds; making local borrowing decisions; making decisions about transferring funds from the relevant local budget; making decisions on granting local tax and levy benefits, as well as land tax, etc. in accordance with applicable law.

4. Powers of environmental orientation. Local self-government bodies also have certain powers in regulating land and other natural resources relations, including through: approving land tax rates; resolving issues of permitting special use of natural resources of local importance, as well as revoking such permission; making decisions on the organization of the territories and objects of the nature reserve fund of local importance and other territories subject to special protection; submitting proposals to the relevant state bodies for the announcement of natural and other objects of ecological, historical, cultural or scientific value, protected by law, monuments of nature, history or culture, making decisions on announcements in the places of mass reproduction and breeding of offspring wild animals of "silence season" with restriction of economic activity and extraction of wildlife objects; granting consent for placement in the territory of a village, settlement, city of new objects, including places or objects for waste disposal, the sphere of environmental impact of which in accordance with the current regulations includes the relevant territory; resolving issues in the field of hazardous waste management and the like.

From the above it can be seen that the powers of local self-government bodies represent a number of rights and obligations aimed at securing the tasks assigned to them in those spheres of public life that relate to the interests of the local population constituting territorial communities of villages, towns and cities. At the same time, it is important not only to have a certain system of competencies for the accomplishment of the tasks set, but also to directly realize them reasonably for the achievement of the main goal - to achieve the well-being of the population (Babenko et al., 2020). For this purpose it is necessary to study the basic features of life of the respective regions and the range of factors that determine them.

Each region of Ukraine has certain characteristics, which are determined by a set of factors, which are quantitative and qualitative characteristics of the types of resources that affect the level of development of the region, social and economic well-being of the population. Such factors may be of an external nature (that is, objective) of historical and natural origin, as well as of an internal nature, of a subjective origin, as they are formed under the influence of the actions or omissions of certain 
entities, public authorities, bodies local self-government, which shape economic, political, social conditions. Internal subjective factors are also determined by the behavior of the business entities and the behavior of the local population.

Let us consider these factors in more detail. External, objective factors are: geographical location, availability of natural resources, their quantitative and qualitative characteristics, including objects and territories of the nature reserve fund, natural medical, recreational resources, historical and cultural monuments, production and personnel. resources, demographic characteristics of the population, its cultural and spiritual characteristics. Internal, subjective factors include: the legal framework of activity of both the state as a whole and its individual regions, the orientation of state and regional policy, the degree of environmental security, crime rates, the development of transport, social infrastructure and more. Obviously, objective factors should influence subjective factors, and both categories of factors have a significant impact on the development of regions.

According to the National Institute for Strategic Studies, the lack of a unified approach to setting priorities in all regional development strategies in Ukraine is a major problem in formulating priorities in regional development strategies. This leads to the narrowing of the very meaning of the notion of priority and its inconsistency with the strategic dimension of regional development. The reason for this is to focus on the short-term goals of regional development and not take into account their long-term goals of development [5]. The long-term development goals must, first and foremost, ensure the economic and social well-being of both the regions and the country as a whole. The direction to achieve this is to analyze all the factors affecting the state of the regions and to take them into account comprehensively by defining short-term goals as certain ways to achieve long-term goals.

A positive factor, which should be taken into account as a factor contributing to the development of the regions, is a significant strong educational and thus human resources potential. According to the data of the State Statistics Service of Ukraine [6] for the 2018/2019 academic year, there were 282 higher education institutions of Ukraine at the level, such as universities, academies and institutes, where 1322,3 thousand persons were enrolled; as well as 370 institutions of higher education institutions (colleges, technical schools and specialized school), which provided education to 199.9 thousand students. From this number of persons, specialists were trained during the academic year under consideration (excluding those who continue their studies in order to obtain a higher level of education):

Table 1. Number of graduates of higher education institutions by education sectors for 2018/2019

\begin{tabular}{|c|l|l|}
\hline Education field & $\begin{array}{l}\text { Number of graduates during } \\
\text { the 2018 \2019 academic } \\
\text { year with an educational } \\
\text { qualification Junior Specialist }\end{array}$ & $\begin{array}{l}\text { Number of graduates } \\
\text { during the 2018 \2019 } \\
\text { academic year with a } \\
\text { bachelor's degree }\end{array}$ \\
\hline $\begin{array}{c}\text { Education (including pedagogical } \\
\text { education) }\end{array}$ & 4006 & 140 \\
\hline The humanities and the arts & 3612 & 53 \\
\hline Law & 1691 & 816 \\
\hline Health care & 187 & 7 \\
\hline Engineering & 7340 & 90 \\
\hline Construction and architecture & 1699 & - \\
\hline Surveying and land management & 219 & - \\
\hline $\begin{array}{c}\text { Agriculture, forestry and fisheries } \\
\text { and processing of their products }\end{array}$ & 1260 & 11 \\
\hline Agricultural engineering and energy & 995 & - \\
\hline Natural Sciences & 8934 & - \\
\hline Service sector & 678 & 12 \\
\hline Security & 30 & - \\
\hline Source: the table is compiled by the authors on the basis of data of the State Statistics Service of Ukraine \\
\hline
\end{tabular}


The above data show that the country is training specialists in different fields of knowledge, and that a significant number of people after reaching the educational-qualification level, the bachelor continues his studies in order to obtain a master's level of education, which positively characterizes the general adjustment of students to master more high level of knowledge. The development of human resources also consists in improving the professional qualification level of the population, constant updating of knowledge, which should be promoted by the number of higher education institutions and the quality of educational services provided by them. Education reform is now underway to transform Ukrainian education into an innovative environment, in which pupils and students will acquire the key competences necessary for every modern person to be successful, and scientists will have the capacity and resources to conduct research that will directly affect the socioeconomic situation the state. Although the reform process is still ongoing, some of the benefits of this reform are already being felt by teachers and students alike. Attention should be paid to certain disadvantages inherent in the current state of educational institutions, in particular, insufficiently high salaries of teachers, which in turn has a negative impact on the corruption level in the educational field, outdated, poorly updated material and technical base of higher education, lack of resources for adequate logistical support of the educational process, which automatically leads to a decrease in the quality of education, especially for technical and natural sciences, etc. These shortcomings are mainly financial and economic in nature, their solution depends largely on the volume and sources of financing.

Demographic and social factors are a significant factor in determining the priorities for regional development.

Table 2. Population of Ukraine, taking into account its division into urban and rural population [7]

\begin{tabular}{|c|c|c|c|c|}
\hline Year & $\begin{array}{ll}\text { Number } & \text { of } \\
\text { population } & \text { of } \\
\text { Ukraine } & \end{array}$ & $\begin{array}{l}\text { Number of urban } \\
\text { population }\end{array}$ & $\begin{array}{l}\text { Number of rural } \\
\text { population } \\
\text { towns) }\end{array}$ & $\begin{array}{l}\text { Demographic burden } \\
\text { on the population aged } \\
15-64 \text { (per } 1000 \text { people } \\
\text { aged } 15-64)\end{array}$ \\
\hline 2008 & 46258189 & 31627980 & 14630209 & 435 \\
\hline 2009 & 46053331 & 31555771 & 14497560 & 429 \\
\hline 2010 & 45870741 & 31483215 & 14387526 & 425 \\
\hline 2011 & 45706086 & 31411262 & 14294824 & 419 \\
\hline 2012 & 45593342 & 31378516 & 14214826 & 421 \\
\hline 2013 & 45489648 & 31357506 & 14132142 & 425 \\
\hline 2014 & 43001209 & 29707091 & 13294118 & 432 \\
\hline 2015 & 42844907 & 29627926 & 13216981 & 443 \\
\hline 2016 & 42672529 & 29532959 & 13139570 & 452 \\
\hline 2017 & 42485473 & 29428016 & 13057457 & 462 \\
\hline 2018 & 42269802 & 29313845 & 12955957 & 470 \\
\hline
\end{tabular}

Based on Table 2, we can conclude that the population of Ukraine as a whole (urban and rural population) is significantly reduced. Such a decrease in the number of the population occurs as the ratio of the number of disabled people (persons aged 0-14 years, 65 years and older) to the number of able-bodied population (aged 15-64) increases. In order to study the accessibility of: health care services, medicines and medical goods, as well as to obtain information on self-assessment of health status and morbidity of the population, the State Statistics Committee in October 2017. conducted a survey of 8,0 thousand households that took part in a sample survey of their living conditions. Almost every second person rated their health status as "good" (Appendix 1). The highest proportion of such persons (81-78\%) was among adolescents and young people aged 18-29 years and children under 14 years (estimated by parents). $61 \%$ of men and $53 \%$ of women reported good health. $11 \%$ of men and $6 \%$ of women older than working age felt good. «Satisfactory» considered their health status $41 \%$ of the population: among adults $-45 \%$, among children under 14 years $-21 \%$, and among adolescents 
under 18 years $-17 \%$. One in ten people said they had «poor» health. The largest proportion of the poorly-affected population was observed among people of incapacitated age: this is how every third woman and every fourth person estimated their health status. In the European Union countries, two thirds of people aged 18 and over rated their health status as good, one in four, and $9 \%$ rated their health status as "poor». In Ukraine, there are $43 \%, 45 \%$ and $12 \%$ respectively [8]. The availability of health care depends largely on the financial capacity of the population, which is driven by the high cost of medicines, medical supplies, and healthcare. In Ukraine, medical reform is ongoing, aimed at guaranteeing the state of the availability of medical services for the whole population of Ukraine, on the one hand, and on the other, attracting public funds to finance certain health services. The state plans to fund emergency, primary, outpatient, hospital and palliative care services within the framework of the medical guarantee program. It is about creating a list of fully paid care services by the state. A specific list of such medical services is planned to be formed annually, based on the needs of the population in health care, the priorities of the state policy in the field of health care and the amount of available funds in the State budget. Individuals are encouraged to pay for services such as non-emergency dentistry, referral to a doctor without referral, aesthetic medicine, etc.

The promotion of social and demographic growth by the activities of local self-government bodies is possible through the creation of targeted health support funds for the population of the respective regions, or some of its poor people, trust funds for families with many children, and so on. However, such activity is only possible due to the availability of sufficient funds in the budget of the respective territorial communities (saeed et al 2020).

In general, demographic and social indicators depend largely on the overall level of economic development of the country. The economic growth of the country and its regions may be a factor contributing to the improvement of the current demographic situation.

It should be noted that the economic factors for the development of the regions depend directly on the saturation of a particular region with economic objects and economic ties. The main negative economic factors that adversely affect the development of the regions of Ukraine can be called: insufficient financial resources of local budgets, dependence on financial assistance from the state, in particular subventions, lack of active action by local authorities on alternative sources of regional development. In addition, such crises in society as the decline of the national Ukrainian currency, the decline in markets for products and services, coupled with the decline in real incomes of the Ukrainian population, lead to the decline of enterprises and contribute to the further decline of the Ukrainian economy. The reasons for the decline of enterprises, in particular those located far from the powerful regional centers of the country, include: low level of production of goods and services, as well as insufficient volume of production of agricultural products; lack of natural technology in industrial activities related to the use of natural resources; reduction of competitiveness of enterprises at the expense of poor quality of goods and services; underdeveloped transport infrastructure, including the poor quality of road pavement that connects remote areas with large regional centers; insufficient level of development of industrial and social infrastructure, which leads to a decrease in investment and thus prevents the creation of new jobs. The competitiveness of individual businesses directly affects the level of economic security and the region concerned. The tasks of local self-government bodies are to create within their legislatively established opportunities comfortable conditions for the activity of already existing enterprises, and for the development of investment in the creation of new business entities. For this purpose it is necessary to make a comprehensive assessment of the disadvantages and advantages of each factor affecting the state of development of a particular sphere of business activity in order to identify and maintain the most promising one. At the same time, local self-government bodies should be sufficiently adapted to the processes of changing public needs in general and entrepreneurship needs in particular.

Ukraine is unique in its geographical location, it is located in the heart of Europe, has unique natural and climatic conditions, a significant number of natural, historical, cultural and ethnic, religious sites, has a strong educational potential. All these positive factors must be involved to ensure the economic growth of both the country as a whole and its individual regions. One of the priority areas for attracting 
these factors to ensure the growth of economic and social development of the regions can be considered tourism.

According to the UN World Tourism Organization (UNWTO), the contribution of tourism to the world gross domestic product, with indirect effects, is 10 percent. The total number of jobs directly or indirectly related to the tourism sector is 11 percent. In 2015, the share of international tourist arrivals increased by 4.4 percent to 1184 million tourists. In more than 40 countries, tourism is a major source of national budget revenue. For example, in Spain, the share of revenues from foreign tourism in total exports of goods and services is 35\%, in Cyprus and Panama - over 50\%, in Haiti-over 70\% [9]. There are the following types of tourism: urban tourism; environmental (green); ethnic; rural; cultural and cognitive; event; medical, medical and wellness; gastronomic; religious; mountain, sports, cycling; adventurous and active; scientific and educational; cruise and yacht; shopping and leisure tourism; other priority types of tourism. The sphere of tourism and resorts is becoming one of the major industries, affecting the general condition and economic trends of a large number of countries in the world.

The need to develop inbound and domestic tourism is driven by the objective need to preserve the environment, natural resources, cultural heritage, human potential and its spirituality, address employment and unemployment issues that are relevant today for small Ukrainian cities [10].

In Ukraine, there is already an understanding of the importance of tourism as a potentially attractive area of development, as indicated by the approval of the Tourism and Resort Development Strategy for the period up to 2026 [11], the main strategic objectives of which are:

- creation of a competitive national tourism product on the basis of systematic marketing activities aimed at clear positioning of different types of tourism products, adapted to the requirements and expectations of consumers;

- ensuring effective and integrated (economic, social, environmental and innovative) use of existing tourist and resort-recreational potential by solving the problem of recreational use and protection of the natural environment and improving the territorial structure of tourism and resorts in order to develop tourist territories, branding territories;

- systematic improvement of the quality of infrastructure of resorts and recreational areas through the implementation of a comprehensive program of step-by-step improvement of the material and technical base with the use of cluster models, public-private partnerships and social ordering;

- improvement of information infrastructure of recreational and tourist services by creating tourist information centers and promoting tourist products during the fair, festival and exhibition activities;

- ensuring the price and quality of tourism products by creating conditions for optimizing the organizational and economic structure of the activities of small and medium-sized businesses in the tourism sector and developing national standards for the provision of tourism services in accordance with international standards;

- organization of the system of qualitative preparation, retraining and advanced training of specialists of tourist support and service, other professions of tourism and resorts.

These strategic goals should only be achieved through concrete action by central government bodies, public authorities at local level with the compulsory support and interaction of local governments.

The development of the tourist services market is also influenced by a number of factors, namely: demographic changes, material and social status of the population, educational level, length of vacation, professional employment, etc. There is a clear link between tourism development trends, overall economic development and personal incomes. The tourism market is very sensitive to changes in the economy. With stable prices, a $2.5 \%$ increase in personal consumption can increase tourism spending by $4 \%$, and a $5 \%$ increase in personal consumption increases this cost by $10 \%$ [12]. Taking into account the above factors of the difficult economic and demographic and social situation in the 
country, it is more effective to stimulate the development of foreign tourism, which will help attract both domestic and foreign investments.

Table 3. Number of foreign nationals who came to Ukraine, in particular for tourism [13]

\begin{tabular}{|c|c|c|c|}
\hline Year & $\begin{array}{c}\text { Total number of } \\
\text { foreign nationals who } \\
\text { came to Ukraine }\end{array}$ & $\begin{array}{c}\text { Number of foreign } \\
\text { nationals who came to } \\
\text { Ukraine for tourism }\end{array}$ & $\begin{array}{c}\text { Percentage of the number of } \\
\text { foreign nationals who came to } \\
\text { Ukraine for tourism purposes to the } \\
\text { total number of foreigners who } \\
\text { came to the territory of Ukraine }\end{array}$ \\
\hline 2011 & 21415296 & 1225954 & $5,72 \%$ \\
\hline 2012 & 23012823 & 940052 & $4,08 \%$ \\
\hline 2013 & 24671227 & 488496 & $1,98 \%$ \\
\hline 2014 & 12711507 & 146804 & $1,15 \%$ \\
\hline 2015 & 12428286 & 137906 & $1,11 \%$ \\
\hline 2016 & 13333096 & 172848 & $0,27 \%$ \\
\hline 2017 & 14229642 & 38958 & $0.27 \%$ \\
\hline
\end{tabular}

Source: the table is compiled by the authors on the basis of data of the State Statistics Service of Ukraine

The data in Table 3 indicate significant losses in the tourism industry in recent years, resulting in, respectively, declining tourism revenues, declining hotel services, reducing investment in tourism infrastructure and job cuts.

Such a state of the tourism industry is caused by a large number of negative factors, including the following: neglect of international experience in tourism development; lack of consistent state policy in the branch; inefficiency of activity of central executive bodies in the sphere of tourism; lack of proper conditions for the development of inbound and inland tourism priorities for the state, tax and financial incentives for the state to export tourism services and domestic tour operators engaged in this type of activity; unsatisfactory work on the formation and strengthening of the tourist image of Ukraine, development and promotion of the national tourist product in the international and domestic markets $[14$, p. 47]. These reasons are quite broad. Agreeing to the reasons stated above, one should also add such negative factors for the tourism industry as well as for the country as a whole, such as the temporary occupation of certain territories of Ukraine and the military conflict in the east of the country. It should be noted that these negative factors are of a general nature, the prospect of overcoming them depends on those actions that can be implemented at the national level [15]. However, it is also possible to identify ways to reduce the impact of these and other negative factors through the activities of local governments within the powers provided by the current legislation [16]. The development of tourism as one of the promising areas of regional development can be ensured through the implementation of the following activities: participation in international and regional tourist exhibitions in Ukraine and abroad, conducting a comprehensive advertising and information campaign in major foreign markets, etc.

\section{Conclusion}

A significant number of factors affect the state of development of the regions, so it is not easy to choose directions, the support of which at the national and local government levels, will lead to positive changes in the well-being of the population. Local self-government bodies should take into account a variety of factors, including geographical, demographic, human resources, environmental, economic, historical and cultural factors, in determining priority directions for the development of regions. The basis for selecting priority areas for regional development should be a comprehensive analysis of all existing factors, taking into account short and long-term development prospects. Local self-government bodies can use tax, information, innovation and other measures of influence to stimulate priority areas for regional development. One of the promising directions of development of the regions of Ukraine is the tourism sphere. Ukraine has sufficient resources to select different types of tourism as a way of supporting local governments for economic and social growth. 
Local self-government bodies in the future directions of regional development should fulfill the following tasks:

1. Information sphere: improving the information support of the tourism industry by conducting wide-ranging promotional activities regarding monuments, places related to historical events, territories and objects of nature conservation fund, large enterprises and other places that may be of interest as domestic and foreign tourists; holding fairs, festivals, holidays with wide publicity of these events by the media; creation of regional information and reference systems in the field of tourism; intensification of advertising activity in national and world social networks. Improvement of information support for the provision of quality educational services to institutions of all forms of ownership located in the territory of the respective region, holding trade fairs of professions that may be acquired by persons in educational institutions of the regions, attracting foreign students to study at regional educational institutions. Information and advertising support for investing in other areas of business, in particular: industry, construction, agriculture, etc.

2. Sphere of international and interregional cooperation: participation in interregional and interstate associations and other organizations that promote information, experience and other exchange, realization of common interests in the development of tourism, involvement in education in educational institutions of regions of domestic and foreign population, in the population, agricultural and other areas of entrepreneurship and more.

3. The sphere of formation of investment attractiveness: reconstruction and expansion of tourist sites located within the respective region, stimulation of attraction of private investments in this sphere of activity; improvement of transport and logistics system, quality of road pavement; development of social sphere and others.

4. Sphere of economic stimulation of local population for activation of business activity: reduction of tax pressure by regulating the amount of local taxes and fees; introduction of a regime of preferential taxation on land tax, local taxes and fees for business entities operating in promising areas of activity selected for a particular region, in particular tourism, introducing resource-saving, naturalrenewing technologies into their activities; establishment of trust funds for tourism support, in particular: rural, green, ethnic; support for cinematography and more.

5. Scope of environmental and territorial infrastructure quality assurance: setting priority in resolving the issue of permitting special use of natural resources of local importance to entrepreneurs using environmentally friendly technologies; organization of territories and objects of nature reserve fund of local importance and other territories that are subject to special protection and are of importance as a tourist object; submitting proposals to the relevant state bodies for the declaration of natural and other objects of ecological, historical, cultural or scientific value, protected by law with the nature, history or culture, in order to attract these objects to tourist attractions ; restriction of economic activities, as well as the production of wild animals in order to facilitate their breeding; promoting the development of waste-related business; taking into account the needs of the population, business and the requirements of the tourism sector in resolving the issues of placement on the territory of the administrative-territorial formation of places or objects for disposal of waste, the sphere of environmental impact of which in accordance with the current regulations includes the relevant territory, etc.

\section{References}

1. Alghamdi, A., \& Akbar, M. (2017). Profiling and Evaluation of Implicit and Explicit Storm Surge Models. Int. J. Comput. Theory Eng, 9, 417-421.

2. Konstytutsiia Ukrainy: Zakon Ukrainy vid 28 chervnia 1996 r. № 254k/96-VR. URL: https://www.president.gov.ua/documents/constitution.

3. Kaminska N. V. Mistseve samovriaduvannia: teoretyko-istorychnyi i porivnialno-pravovyi analiz: navchalnyi posibnyk. Kyiv: KNT. 2010. $232 \mathrm{~s}$. 
4. Senchuk V. Mistseve samovriaduvannia i demokratychna derzhava: dialektyka vzaiemozv'iazku i vzaiemnoi determinatsii. Yurydychna Ukraina. 2009. № 6 (78). S. 17-23.

5. Saeed, S., Shaikh, A., \& Memon, M. A. (2018). Impact of Social Networking Sites on Personality \& Attitude of Young Adults (Research covering the young adults" lives within Korangi, Karachi). International Research Journal of Arts \& Humanities (IRJAH), 46(46).

6. Pro mistseve samovriaduvannia v Ukraini: Zakon Ukrainy vid 21.05.1997 r. № 280/97-VR. URL: https://zakon.rada.gov.ua/laws/show/280/97-vr.

7. Shevchenko O. V. Shchodo udoskonalennia rehionalnykh priorytetiv rozvytku u protsesi modernizatsii serednostrokovykh stratehii ekonomichnoho i sotsialnoho rozvytku rehioniv Ukrainy. Analitychna zapyska. Natsionalnyi instytut stratehichnykh doslidzhen. URL: http://old2.niss.gov.ua/articles/1344/

8. Zaklady vyshchoi osvity // Derzhavna sluzhba statystyky Ukrainy. URL: http://www.ukrstat.gov.ua/operativ/operativ2005/osv_rik/osv_u/vuz_u.html.

9. Kilkist naselennia Ukrainy $z$ urakhuvanniam yoho podilu na miske ta silske naselennia (bez tymchasovo okupovanoi terytorii Avtonomnoi Respubliky Krym ta $\mathrm{m}$. Sevastopolia). URL: http://database.ukrcensus.gov.ua/Mult/Dialog/Saveshow.asp.

10.Samootsinka naselenniam stanu zdorov'ia ta rivnia dostupnosti okremykh vydiv medychnoi dopomohy // Derzhavna sluzhba statystyky Ukrainy. URL: http://www.ukrstat.gov.ua/operativ/operativ2018/gdvdg/Arh_snsz_u.htm.

11.Turyzm v Ukraini: kudy yidut naibilshe i yaki napriamy potribno rozvyvaty. URL: http://expres.ua/news/2017/10/05/265404-turyzm-ukrayini-kudy-yidut-naybilshenapryamypotribno-rozvyvaty.

12.Safiullina V. O. Mekhanizmy derzhavnoho rehuliuvannia turystychnoi sfery Ukrainy. URL: http://academy.gov.ua/ej/ej5/txts/07svotsu.htm.

13.Pro skhvalennia Stratehii rozvytku turyzmu ta kurortiv na period do 2026 r.: Rozporiadzhennia Kabinetu ministriv Ukrainy vid 16 bereznia 2017 r. № 168-r. https://zakon.rada.gov.ua/laws/show/168-2017-\%D1\%80.

14.Liashkevych P. Turyzm v Ukraini: Suchasnyi stan ta priorytety rozvytku. Osvita Ukrainy. 2014. № 85. S. 178.

15.Vizd inozemnykh hromadian v Ukrainu za krainamy, z yakykh vony prybuly // Derzhavna sluzhba statystyky Ukrainy. URL: http://www.ukrstat.gov.ua/operativ/operativ2007/tyr/tyr_u/arh_vig.html

16.Stavska Yu. V. Rozvytok turyzmu v Ukraini v umovakh vplyvu faktoriv svitovoho rynku. Ekonomika. Finansy. Menedzhment: aktualni pytannia nauky i praktyky. 2017. № 2. C. 42-49.

17.Babenko, V., Pravotorova, O., Yefremova, N., Popova, S., Kazanchuk, I., Honcharenko, V. (2020). The Innovation Development in China in the Context of Globalization. WSEAS Transactions on Business and Economics, Vol. 17, 2020, Art. \#25, pp. 523-531. https://doi.org/10.37394/23207.2020.17.51

18.Brodin Ye.I., Lenenko I.M. Orhany mistsevoho samovriaduvannia yak ob'iekt reformuvannia $v$ konteksti detsentralizatsii vlady v Ukraini. Publichne administruvannia: teoriia ta praktyka, 2016. Vyp. 2 (16). URI: http://www.dridu.dp.ua/zbirnik/2016-02(16)/25.pdf.. 